Texas A\&M University-San Antonio

Digital Commons @ Texas A\&M University-San Antonio

2018

US Equity Crowdfunding: A Review of Current Legislation and A Conceptual Model of the Implications for Equity Funding

Lynda Y. de la Viña

Stephanie L. Black

Follow this and additional works at: https://digitalcommons.tamusa.edu/mgmt_faculty

Part of the Business Administration, Management, and Operations Commons, and the Entrepreneurial and Small Business Operations Commons 


\title{
U.S. EQUITY CROWDFUNDING: A REVIEW OF CURRENT LEGISLATION AND A CONCEPTUAL MODEL OF THE IMPLICATIONS FOR EQUITY FUNDING
}

\begin{abstract}
Recently developed SEC guidelines provide the regulatory framework for Title II of the Jump Start our Business (JOBS) Act of 2012, which legalizes interstate equity crowdfunding in the United States. Concurrently, eighteen states have passed legislation or promulgated regulations that allow intrastate equity crowdfunding. At present, the literature has not addressed what this nascent funding mechanism will offer to investors, as well as, those seeking funding for entrepreneurial projects within the U.S. Therefore, this paper provides a review of current U.S. legislation, discusses the anticipated implications of equity crowdfunding, and develops a conceptual model that demonstrates potential outcomes.
\end{abstract}

Keywords: crowdfunding, equity crowdfunding, intrastate equity crowdfunding, 
Over the last few years, crowdfunding has expanded to create dynamic global funding networks. Crowdfunding enables projects to be financed via the Internet thru solicitation of small investments in the form of a donation or in exchange for a reward or voting rights from a large base of potential backers (Zvilichovsky, Inbar, and Barzilay 2013; Collins and Pierrakis 2012; Cholakova and Clarysse, 2014; Hemer, 2011; Lambert and Schwienbacher, 2010; Kleemann, Voss and Reider 2008). Bradford (2012) defines crowdfunding as 'the use of the Internet to raise money through small contributions from a large number of investorsl' (1), 'rather than professional parties such as banks, venture capitalists or business angels' (Schwienbacher and Larralde 2010, 4). Crowdfunding is a unique mechanism for raising funds because it 'uses collective decision making via a social media platform to evaluate and raise financing for new projects or new commercial ventures’ (Bruton, Khavul, Siegel, and Wright 2015, 12).

The literature discusses three main types of crowdfunding: token investment, lending investment and equity investment. The first, token investment is among the most common and refers to individuals that give donations to support a cause or project without any expectations of a financial return. Instead, investors receive either a simple affirmation or non-monetary rewards based on the level of their contributions. The second type of crowdfunding, lending investment, refers to investors' receiving interest on their investment in a company at an established interest rate. An example is the LendingClub.com, which is a loan-based, crowdfunding portal and community that connects borrowers with potential investors. For the purposes of this study, we shall be focusing on the third type, equity crowdfunding (ECF), which refers to investors that receive shares or units in a business in exchange for their financial investment in that firm.

Equity crowdfunding (ECF) is particularly interesting because the overall global crowdfunding volume is estimated to increase to $\$ 35$ billion by 2020 (Blohm, Sieber, Schulz, 
Haas, Leimeister, and Wenzalff 2014), and the equity-based and lending-based crowdfunding models are expected to expand and reach a market share of approximately $60-80 \%$ globally. According to an Industry report by Mass Solutions (2015), globally ECF raised $\$ 11.08$ billion dollars in 2014 and is expected to continue to have accelerated growth by doubling in size annually over the next few years. Moreover, ECF is expected to overtake venture capital as the largest source of startup funding by 2020 ( $\$ 36$ billion) (Emmerson 2015).

The first country to adopt equity crowdfunding was the United Kingdom, with Crowdcube as the first platform, and since that time ECF has rapidly expanded into other countries. In 2013, the World Bank reported 672 crowdfunding sites and estimated a world crowdfunding market of $\$ 96$ billion (Worldbank 2013). However, primarily due to concerns over the potential for fraud and the need to protect investors (Brutan et al. 2015), the U.S. has been slow to adopt ECF. Particularly within the U.S., equity crowdfunding has experienced regulatory roadblocks due to adherence to the regulations of the Securities Act of 1933, but with the passing of the JOBS Act in 2012 and the finalization of regulations by the Securities and Exchange Commission in 2015, the U.S. legislators established the ECF in the U.S.

The Jump Start Our Business Startups (JOBS) Act of 2012 effectively brings securities regulation into the era of social networking by enabling ECF to occur via an on-line market (Miller 2013). With the new regulations in the U.S., research on ECF is nascent, and the extant literature has not fully addressed the implications of this funding mechanism and the possibilities it will offer to the "crowd" investors within the U.S. Thus, the transition from token rewardbased funding to equity-based funding via crowdfunding platforms merits further review and more analysis (Cholokova and Clarysse 2014). Also, since U.S. federal and state legislative changes are occurring in real time, the equity crowdfunding apparatus and its critical 
implications also merit timely review. Therefore, this paper seeks to provide a systematic review of the emerging ECF investment environment in the U.S. in three ways: (1) comparing traditional equity-based financing regulations to the new federal JOBS Act; (2) comparing state ECF laws to the JOBS Act; and (3) introducing a conceptual model which can be the basis for future empirical research and theoretical extensions and lastly (4) discussing and depicting some of the potential implications and the potential of both intrastate and interstate ECF for the effective funding of future entrepreneurial ventures in the United States.

\section{REVIEW OF LITERATURE}

With the global expansion of crowdfunding, it has gained more attention however, we still lack a comprehensive understanding of crowdfunding and many topics related specifically to ECF (Gierczak, Bretschneider, Haas, Blohm, and Leimeister 2016). Research has primarily focused on venture capital, bank loans, and angel investments (Bygrave 2009; Moss, Neubaumm, and Meyskens 2014) or on non-equity (token/reward) crowdfunding rather than ECF (e.g. Cholakova et al. 2014). Although equity crowdfunding research has been conducted in other countries (e.g. Décarre and Wetterhag 2014; Hornuf and Schwienbacher 2014b; 2015; Hornuf and Neuenkirch 2015; Vismara 2015). Research on ECF for non-accredited investors within the U.S. is rather nascent due to data limitations, particularly in peer-reviewed journals (Mollick 2014). At present, most of our knowledge on ECF has been obtained from markets outside the U.S.

Some of the extant research has examined various aspects of crowdfunding such as the effective use of crowdfunding (Schwienbacher and Larralde 2012), various types of customers (Ordanini, Miceli, Pizzetti, and Parasuraman 2011), the selection of crowdfunding platforms (Belleflamme, Paul, Thomas Lambert, and Armin Schwienbacher, 2014), , the decisions made by 
investors, as well as, the geographical bias of investors (Agrawal, Catalini, and Goldfarb 2011;

Lin and Visvanathan 2015), the motivations of individual investors (Cholokova and Clarvasse 2014), and the information dimensions to attract investors (Parker 2014). Another study by Ahlers, Cumming, Gunther, and Schweize (2012) pursued empirical research by utilizing the Australian ASSOB platform as the source of their ECF data. Their study showed that in the Australian market, successful equity crowdfunding initiatives rely on equity retention decisions and detailed information on investor risks, including credible signals, quality of the start-up, and sound information disclosure to the "crowd." Other equity crowdfunding studies showed that accumulated capital that is invested in projects can serve as an informative, but noisy, signal of project quality (Agrawal et al. 2011; Burtch, et al. 2013). Another study by Cholokova and colleagues (2014) examined the motivations of individuals to pledge to reward-based projects and invest in equity-based platforms and showed that investing for equity is a positive predictor of keeping the pledge. Other studies have reviewed the information dimensions. For example, the work by Parker (2014) investigated the information dimension in equity crowdfunding and showed that "information cascades" can mitigate the problem of thoroughly communicating private company information, but also that without inclusive information "cascades" investors will tend to spread (financial) resources so thinly that few good projects achieve the funding that they require.

Some commonalities that have been identified thru the research in both non-equity and equity crowdfunding indicate various factors that should be considered for a successful crowdfunding experience which include:

- the importance of entrepreneurial signaling to small investors regarding the value of the project. The findings of Ahlers, et.al. (2012) for entrepreneurs utilizing crowdfunding 
showed that signaling elements such as performance based signals (financial projects and strategic plans) can increase the likelihood of success. Moreover, structure of firm internal governance structure can enhance the likelihood of attracting investors and the speed of raising capital.

- the importance of having efficient public information retrieval via social media. Parker's (2014) study showed that investors face asymmetric interactions, but that information cascades can mitigate the problem.

- consideration of the inherent geographical bias that may potentially occur. Lin and Vishvanathan's (2014) study showed that home bias exists in the virtual marketplace whereby investors will forgo a better alternative (lower risk, high return) in favor of investing in their home state. Agrawal and associates (2011) discuss the importance of geographical dispersion of investors, especially during early financing stages.

- the importance of establishing relationships and legitimacy using the crowdfunding infrastructure. Schwienbacher and Lerralde (2012) stress the importance of building a community of crowdfunders for greater engagement as well as developing the ability to tailor crowdfunding initiatives (Belleflamme, Lambert, and Schwienbacher 2013).

\section{Institutional Concerns Regarding Equity Crowdfunding (ECF) in the U.S.}

Scholars have also tried to highlight the institutional challenges posed by the equity crowdfunding phenomenon. Bedino and Castrataro (2012) state that the European equity crowdfunding market is still in flux, given the presence of different national regulations. The variance in regulatory frameworks has also been of concern the United States (Ortmans, 2015). Recent legal studies have explored the regulatory framework currently being developed in the 
United States for the equity crowdfunding market (e.g. Schwartz 2013; Bradford 2012). These legal studies are the only guideposts for analyzing the developing ECF phenomenon in the U.S. However, given the recent changes that have occurred both in National and State legislation, we contend that it is important to extend the existing literature by: (1) focusing on the evolution of U.S. equity crowdfunding legislation and its regulatory framework, (2) enumerating and discussing the anticipated implications for the emerging equity crowdfunding market; and (3) depicting ECF via an emergent conceptual crowdfunding model.

\section{THE FEDERAL EQUITY FUNDING REGULATIONS AND THE RISE OF CROWDFUNDING}

On April 15, 2012, the JOBS Act, was signed into law, effectively superseding Rule 501 of Regulation D of the Securities Act of 1933 by allowing the "crowd" to participate in equity investments. At present, the Securities and Exchange Commission (SEC) has finalized Titles II and IV and has yet to finalize the Title III regulations associated with the JOBS Act. However, one of the primary objectives of the JOBS Act is to relax regulations on small business equity funding and private placement activities by legalizing equity crowdfunding (ECF) by nonaccredited investors. The JOBS Act allows for the creation of the crowdfund exemption, allowing small investors to participate at any funding stage and secondly, entrepreneurs are allowed to raise capital by direct solicitation of funds including advertising

Prior to the JOBS Act, equity crowdfunding in the U.S. had only limited applicability to facilitating investments in start-up and small to medium enterprises (SMEs) because the offerings did not fit into any of the pre-JOBS Act private placement exemptions under the Securities Act or under applicable state securities or blue sky laws, which regulate the offering 
and sale of securities to protect investors from fraud. While successful ventures, such as Google, Apple, and Facebook, have the potential to provide high returns for investors, many ventures do fail during their formative years, with investors losing their capital. Various studies have shown that $75 \%$ to $90 \%$ of start-ups fail (Gage 2012). Due to the high risk involved when investing in new ventures, the government developed regulations to protect investors whereby start-up investment opportunities have been limited to "accredited investors." The federal securities laws define the term "accredited investor" (AI) in Rule 501 of Regulation D and detail the various types of accredited investors, such as individuals, banks, insurance companies, registered investment companies, business development companies, or small business investment companies. The parameters for accredited investors also indicate that these investors must possess a minimum liquid net worth of at least $\$ 1$ million, excluding the value of a primary residence, or an annual income of $\$ 200,000$ (\$300,000 with a spouse). What is clear from the above definition of SEC "accredited investors" is that AI's are thus composed of only high net worth/high income individuals or large institutional investors. Therefore, the general population or "Crowd" has not been privy to equity investments of any type or size.

\section{Review of New SEC Guidelines: Title IV (Regulation A+) and Title III}

The new guidelines are expected to ensure that the new rules will achieve their intended effect on private capital formation while still protecting investors from fraud (McDermontt, Will, and Emory 2013). According to Fowler (2015) the SEC equity crowdfunding (ECF) guidelines in Title IV (Regulation A+) state that:

(1) Entrepreneurs are allowed to solicit and publicize their pursuit of equity funding.

(2) Companies may offer and sell securities through a crowdfunding portal so long as 
transactions comply with certain requirements via Section 4(6) (the "Crowdfunding

Exemption"). Only companies that (a) are domestic entities, (b) are not subject to the reporting and registration requirements of the Exchange Act (Tier II exemption from reporting and registration, however, there is a 2 year transitional time period and the issuer must have less than $\$ 50$ million in revenues at last completed fiscal year), and (c) are not investment companies.

(3) Crowdfunding transactions in Tier 1 may raise up to $\$ 20$ million in Regulation A offerings in any 12 month period. Tier 2 consists of up to $\$ 50$ million in Regulation A offerings in any 12 month period. (4) Anyone within the "Crowd" may invest. The guidelines do not require investors to be U.S. Accredited Investors. For Tier 1 investments, which have a lower cap, there is no investment limit on investors. However, additional Tier 2 requirements include a limitation on the amount of securities, non -accredited investors can purchase in a Tier 2 offering. An investor may purchase no more than (a) $10 \%$ of the greater of annual income or new worth (natural person); or (b) $10 \%$ of the greater of annual revenue or new assets at fiscal year (for nonnatural persons). (5) The bad actor rules disqualify certain issuers and other market participants from using Rule 506 if certain "bad actors" are participating in the offering. (6) Tier 2 also requires additional financial disclosure and ongoing reporting requirements. (Please refer to

\section{Appendix 1 for a comparison of JOBS Act Title II, III, and IV (A+) regulations).}

Furthermore, as of October 30, 2015, the SEC voted on the proposed rules under the JOBS Act to permit companies to offer and sell securities through crowdfunding, but Title III will officially not become effective until January 29, 2016 (SEC 2015). Title III of the Jobs Act is designed to allow non-accredited investors to invest and participate in start-up businesses by effectively establishing the foundation for a regulatory structure that will enable entities to use crowdfunding. Title III also creates and requires a new entity, a funding portal, to allow Internet- 
based platforms or intermediaries to facilitate the offer and sale of securities without the need to register with the SEC as brokers. These measures are intended to facilitate small businesses in raising capital while at the same time protecting investors.

Title III SEC guidelines state: (1) Issuers are limited to raising \$1 million per year; (2) the offering is available to the general public with no limit to the number of investors; (3) Issuers do not need to comply to individual state's filing and disclosure requirements; (4) All solicitation to investors must be done through a portal or a broker dealer intermediary registered with the SEC and FINRA; (5) Investors with income or new worth above $\$ 100,000$ can invest up to $10 \%$ of their net worth or income up to $\$ 100,000$. Investors with income or net worth below $\$ 100,000$ may invest the greater of $\$ 2000$ or $5 \%$ of annual income or net worth; (6) Some financial disclosure is required by issuers including GAAP financial statements for past two years (crowdexpert.com 2015).

Overall, the private placement exemptions from the Securities Act of 1933 have provided a narrow bandwidth for start-ups to raise capital, given accredited investor wealth requirements, and the prohibition on general solicitations by start-ups. According to a recent survey, $97 \%$ of U.S. respondents noted they would invest in startups given the opportunity. However, $63 \%$ of respondents don't qualify as Accredited Investors (\$200k/year in income or \$1 Million plus in the bank) (Alois 2015). However, Title III will effectively allow this large group of individuals an opportunity to invest in early stage companies, which were previously reserved for wealthier investors. The JOBS Act, was specifically designed to facilitate small investments by many people with the expectation of creating a larger pool of investment funding. This larger pool of funds from the "Crowd" not only infuses the equity financing continuum with new capital, but it also ultimately produces greater "democratization" of equity capital across a larger spectrum of 
the population (Blechman 2012).

\section{STATE LAWS PERTAINING TO CROWDFUNDING}

With the passing of the JOBS ACT and even prior to the promulgation of the SEC rulings, U.S. states enacted, and indeed are continuing to enact, their own crowdfunding exemption laws for intrastate investment offerings that are exempt from federal SEC regulation. As of August 2015, 29 states and the District of Colombia have either enacted separate intrastate crowdfunding exemptions or have enacted amendments to their existing blue sky laws to permit some type of intrastate crowdfunding (Zeoli 2015). These states are Alabama, Arizona, Colorado, DC, Florida, Georgia, Idaho, Illinois, Indiana, Iowa, Kansas, Kentucky, Maine, Maryland, Massachusetts, Michigan, Mississippi, Montana, New Jersey, Nebraska, Tennessee, Texas, Vermont, Virginia, Washington, and Wisconsin. Eight other states are either in the process of enacting or considering legislation regarding intrastate crowdfunding, and they are: Alaska, Hawaii, Missouri, Nevada, New Hampshire, New Mexico, North Carolina, and West Virginia (crowdfundinglegalhub.com 2015). At present, 4 states have rejected proposed intrastate crowdfunding, California, Florida, North Carolina, and Utah. However, given the tremendous growth in equity crowdfunding activities throughout the world and the protracted formulation of SEC regulations, it is highly likely that more states will pass their own legislation to allow equity crowdfunding. Therefore, it is important and indeed timely to review equity crowdfunding legislation at all governmental levels in the U.S.

\section{U.S. FEDERAL AND STATE COMPARISION}

After reviewing the current legislation, we identified eight critical departures between federal and state crowdfunding legislation. They are comprised of: registration, limits on offerings, investment caps on issuers; preemption, requirements on notification, regulations on the 
use of intermediaries, required filings, and post offering reporting. Our analysis shows: First, that the states' standards for registration are similar to the federal standard but, they extend the registration only to registered entities within the state and require solicitation of funds only from residents within their own state. Secondly, state legislation typically mandates that the total amount of securities an issuer may sell to individual investors shall not exceed \$1 million per year, which is reflective of federal Title III regulations (SEC 2015). Under certain investor conditions, that investment may rise to $\$ 2$ million in some states. Federal Title IV (A+), however, has substantially expanded the issuer limits in both Tier 1 and Tier 2 as compared to the states. Thirdly, both levels of government base their limits on the individual investor's annual income or net worth; however, the limits differ substantially. The current Title IV $(\mathrm{A}+)$ limit for Tier 1 has no limit and Tier 2 is $10 \%$ of income or net worth (for a natural person), while states allow investment by individuals with less than $\$ 100,000$ in income or net worth and allow their participation at a lower investment amount, as low as \$2000. Fourthly, requirements on notification are similar, and each level of government has processes that must be followed by the issuers. Fifth, the Federal JOBS Act specifies that crowdfunding transactions must be conducted through a broker or a "funding portal" registered with the SEC and any applicable self-regulatory organization. Many states, however, do not require a broker or funding portal and, if used, the only requirement is that this portal must allow the state access for a review. However, both the states and the federal government do require specific filings. Finally, the federal government requires, at a minimum, annual reporting of the offerings while the states generally require a quarterly report.

As shown by this analysis, the intrastate crowdfunding regulations, although generally mirroring the federal statutes, do provide for more expansive crowd participation at all levels. 
Moreover, although mindful of the importance of notification to investors and quarterly filings to a state, they do not require a broker or funding portal and allow for direct solicitation via multiple media. In essence, the state laws are more robust and efficient and seek to develop investment vehicles within the state and attract in-state investors at all levels.

The review of both the federal and the state equity crowdfunding laws describes the legal structures that are specifically designed to expand the infusion of capital to U.S. start-ups by allowing the "crowd" to participate. State crowdfunding actions are thus directly related to the recognition of significant geographic bias that was found in previous academic studies. These governmental actions, coupled with the current knowledge of important factors related to successful crowdfunding, lead us to several overarching implications and also to a preliminary modeling of the impact of equity crowdfunding (ECF).

\section{TRADITIONAL FUNDING VS. EQUITY CROWDFUNDING}

In order to develop a conceptual model and introduce the implications of equity crowdfunding, it is important to review what traditional funding offers start-ups and entrepreneurs. In traditional equity funding of start-up enterprises, a temporal path or continuum has developed (Harrison 2013) (See Figure 1). "Pre-seed financing” generally emanates from business plan competitions, university assistance, family, friends and savings (Mixon 2008; Shane 2008). Pre-seed funding is a relatively small amount typically used for proof of concept and prototype development. Second, "seed or start-up financing" expands these funding sources to venture angels, venture angel networks, or debt financing and is provided to newly formed companies for their use in completing product development and initial marketing (Denis 2004). Third, "Series" financing, encompassing various stages, engages formalized investment pools 
created by venture capital firms that provide funds for company expansion and may include plant, marketing, and working capital and, for the development of an improved product, the introduction of a new technology or an expanded product line. Lastly, when the firm is mature but still expanding, such financing may also be provided for a company that is expected to "go public.” This element of series financing is called bridge financing (Metrick and Yasuda 2011). These stages of enterprise financing form the equity-financing continuum that is illustrated in Figure 1 below. It is, however, acknowledged that many successful start-ups have "jumped" the continuum path by locating significant venture investors at the initial stages of development. These instances, however, are not exemplary of most start-up companies that are searching for initial funding.

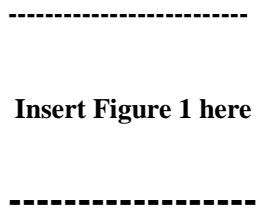

Presently, scholars know little about the dynamics of ECF. In particular, "we do not know whether crowdfunding efforts reinforce or contradict existing theories about how ventures raise capital and achieve success" (Mollick 2014, 2). However, we know that organizations and new venture often seek financing (Gompers and Lerner, 2004; Gorman and Sahlman, 1989; Kortum and Lerner 2000), and ECF is emerging as a means for them to secure funding beyond traditional means (Mollick 2014). However it may or may not substitute for traditional financing. In fact, it may also be used to attract larger venture capital as in the case of Pebble and their "smart watch", which used Kickstarter for its initial funding but later attracted venture funding (Dingman 2013). Nevertheless, we argue that ECF disrupts the financing life cycle because it tends to be predominately in new projects at early stages of development (Mollick 
2014) and it is anticipated that this disintermediation will compress the financial supply chain from "months to days" (Miller 2013) and potentially reduce the current transactions costs for startup ventures to raise capital.

Thus, ECF, via government legislation, now provides a structural element for start-up funding rather than the continuation of the randomness of the private equity market. As shown in Figure 2 below, we contend that ECF will be introduced primarily during the Pre-seed and Seed elements of the continuum (likely after business plan finalization and before or during prototype development, Alpha and Beta testing). It is anticipated that the latter series of elements of the continuum may include an ECF component but are more likely to be funded by the more traditional and formal investment pools made up of accredited investors.

Insert Figure 2 here

The difference between a traditional venture capital firm and an online venture platform, such as the FundersClub, the first online venture capital platform (Grant 2013), is that investors get more exposure to pre-vetted opportunities then they did in the past, where such opportunities were only presented to a select group of wealthy investors. Other online start-up investment platforms for accredited investors have also emerged, including AngelList, Microventures, WeFunder, and Circleup, and the quality of available start-ups and the amount of value provided by them has thus varied by the platform being used. However, as progressive as FundersClub and other venture platforms have been, their focus is still accredited investors. As of yet, in the U.S. the "crowd" has not had the opportunity to pursue active investing via these online sites, and accredited investors participating in the sites are not investing in start-ups and small 
businesses. Presently, there are approximately 8.6 million accredited investors in the U.S., but only $3 \%$ of these investors are currently investing in start-ups and small businesses (Alois 2013).

Over the last ten years, there has been a significant retraction in the capital markets with small businesses not having access to the capital to start and fund their business development (Mills 2014). Therefore, crowdfunding can assist entrepreneurs by offering more access to capital, especially when traditional financing is not readily available (Bruton et al. 2015). As such, crowdfunding platforms can supplement other aspects of private investing and increase the flow of entrepreneurial capital (Financial Conduct Authority 2014). For example, by examining the current average size per transaction on Crowdfund platforms, such as CircleUp, and then taking into consideration the expected acceleration to the "repeat purchase" rate, as well as, the addition to the total amount of investable capital, the total market potential for equity crowdfunding today has a tremendous potential that can exceed many times that of any current online marketplace (Conner 2012). According to the JOBS Act Reg D, the market represents $\$ 1.3$ trillion dollars (regdresources 2015).

Using equity crowdfunding (ECF) as a new funding platform effectively creates a new asset class wherein shares are issued via SEC registered crowdfunding portals or individual state crowdfunding investment platforms. Although not defined by the strict definition of an Initial Public Offering (IPO) that requires significant preparation and oversight, crowdfunding, nevertheless, mirrors an IPO, whereby, the "crowd" is privy to initial company equity on a public platform via an electronic medium. The number of crowdfunding platforms in the U.S. is increasing every year (Mass solutions 2015). Currently, there are approximately 191 crowdfunding platforms in the U.S. (Statista.com, 2015), 56 equity crowdfunding (ECF) platforms (Neiss 2012), and as of August 2015, 29 states that have either enacted intrastate 
crowdfunding exemptions or enacted amendments to their existing blue sky laws, which regulate the buying and selling of securities, to permit some type of intrastate crowdfunding (Mihalik and Lawson 2015). These ECF platforms can substitute for the more traditional intermediaries between supply and demand. We thus argue that crowdfunding can have macro-level implications as proposed by the literature but it can also have micro- or firm-level implications. Based on commonalities in the existing research we have reviewed coupled with implications from government regulation, we contend that with the enactment and implementation of federal crowdfunding and the acceleration in state initiated intrastate crowdfunding, the following will occur:

Proposition 1: Total equity seed funding will increase with the addition of ECF. With the elimination of significant restrictions on issuers, as well as, the predominate use of Internet portals and direct solicitation, proposition 2 follows:

\section{Proposition 2: Time to fund will be compressed with the addition of ECF}

With the increased usage by issuers of low cost Internet portals and the decrease in costs of registration and reporting, proposition 3 follows:

\section{Proposition 3: Transactions costs will decrease with the addition of ECF}

Figure 3 below demonstrates the proposed impact of crowdfunding. The y-axis shows Total Funding (\$), while the $\mathrm{x}$-axis measures Time from "funding ask at $\mathrm{T}_{0}$ to funding close at $\mathrm{T}_{\mathrm{n}}$ ”. The area under Arc 2 (NCF, non-equity crowdfunding curve) shows total equity funding under the "traditional" equity funding methods during pre-seed and seed stages. Arc 1 depicts the addition of equity crowdfunding $(\mathrm{ECF})$ resulting in the $\mathrm{NCF}+\mathrm{ECF}$ arc. As illustrated in Figure 3, total equity funding is the area under each arc. As shown, the area under Arc 1, is 
greater with the addition of equity crowdfunding and the time to fund is compressed from $\mathrm{T}_{2}$ to $\mathrm{T}_{1}$

Insert Figure 3 here

Figure 4 below shows an alternative representation, whereby the NCF with the addition of equity crowdfunding (ECF) rotates the logistic funding curve upward to depict an acceleration of funding per time period due to efficiencies in the portal/platform facility, ability to solicit, and disintermediation (especially in intrastate equity crowdfunding). Once again, $\mathrm{NCF}+\mathrm{ECF}$ illustrates that "time to funding" compresses from $\mathrm{T}_{2}$ to $\mathrm{T}_{1}$. At time $\mathrm{T} 1$, point A shows that total equity funding along the $\mathrm{NCF}+\mathrm{ECF}$ curve at $\$ 1$ is greater than $\mathrm{NCF}$ equity funding $\$ 2$ at point B. If equity funding increases along the NCF curve, the $\$ 1$ level of funding would not occur until point $\mathrm{C}$, thus requiring a longer period to fund at $\mathrm{T} 2$.

Insert Figure 4 here

\section{Implications:}

- $\quad$ Equity Funding is greater, $\$ 1>\$ 2$, at deal closing and

- "Time to Fund" is compressed, $\mathbf{T}_{1}<\mathrm{T}_{2}$;

Based on implications from the literature and from the expected implications of government regulations, the diagrams above represent our concepts and constructs regarding the impact of equity crowdfunding with regard to the temporal equity-financing continuum. We contend that the potential ECF impact is an expansion of capital to start-ups at all initial levels of 
the financing continuum, a compression of the arc time line from "funding ask to investment," and a reduction of transactions costs. As a corollary, we also propose that equity crowdfunding will spread the level of risk across a larger pool of investors. Tysiac in 2014 showed that investors recalibrate their portfolios to reflect a risk spread among the traditional sources of investment allocations and ECF platform allocations. Moreover, since there will potentially be more investors, the risk will be spread over the larger pool, thus mitigating the risk. Data to test these propositions still await the final implementation of Title IV equity crowdfunding regulations by the SEC, and operations by crowdfunding portals on both the national and state levels as well as the construction of data sets either from annual reports or national surveys of ECF portals.

\section{DISCUSSION}

With ECF crowdfunding being allowed in the U.S. we recognize that it has many new implications for small and medium enterprises. At present we can only make limited statements regarding ECF because there are many unresolved questions (Burtch, Benedetto, and Mudambi 2014), which merit further research. However, we contend that ECF in the U.S. may have both positive micro and macro externalities that emanate from the promulgation of both state and federal equity crowdfunding legislation. For example, some of the positive influences that ECF may have are to:

(1) Increase the rate of business start-ups. Equity Crowdfunding has the potential to be an efficient fundraising vehicle for start-ups and other small companies because it provides a new, relatively inexpensive means to find investors outside of the traditional pre-seed and seed rounds that have traditionally focused on angel investors or multiple friends and family. ECF transactions provide companies with the ability to attract investment from, 
"retail" investors who ordinarily cannot be included in traditional private placements (Miller 2014; NSBA 2012).

(2) Encompass a wider range of potential projects and founding goals (Mollick 2014). Crowdfunding also has the potential to be a very attractive fundraising vehicle for start-ups and other small companies because it provides them with a new, relatively inexpensive means to find investors outside of the traditional pre-seed and seed rounds that have traditionally focused on angel investors or multiple friends and family.

(3) Decrease the failure rate of small businesses. According to the Bureau of Labor Statistics, almost half of all start-up businesses fail within two years due to a lack of funding alternatives. Minority entrepreneurs in particular, tend to have more difficulty accessing capital (Ekanam and Wyer 2007; Gaskill, Van Auken, and Manning 1993; Hisrick and Brusch 1986). ECF may provide a viable alternative to traditional funding for that group. According to Stemler (2013), crowdfunding is "uniquely positioned to assist two groups of people in securing the money and support their needs: (a) entrepreneurs trying to turn their ideas into viable businesses, and (b) small business owners trying to keep their businesses afloat or get them to grow" (272) thereby increasing the rate of business start-ups and decreasing the rate of small business failures.

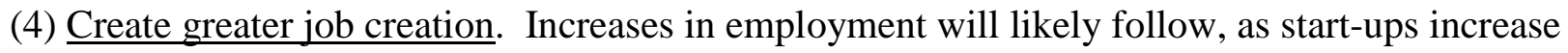
their viability and growth in the United States. According to the U.S. Small Business Administration, the largest employment sector in the U.S. is small business. It accounts for $55 \%$ of the workforce (SBA.gov. 2015), and ECF may allow this sector to expand even further. 
(5) Increase business funding outside major urban areas or innovation hubs. This assumption is a function of the new state crowdfunding laws. The democratization of equity funding, thus, applies not only to an expansion of investors/owners, but also to an expansion of funding to businesses "between the two coasts." (Agrawal 2011; Lin and Viswanathan 2013; Sohl 1999; Stuart and $\mathrm{Xu} 2003)$.

(6) Offers non-financial benefits. According to companies like FUZ Design, the "moneygathering crusade spawned widespread coverage on tech blogs, which led in turn to hundreds of offers of help with marketing, design, manufacturing, and distribution" (Alsever 2015). In fact, most entrepreneurs now rank these other benefits as having higher value than the actual funds that are garnered (Alsever 2015). Indeed, money tends to rank fourth or fifth in status for most companies (Alsever 2015). Often these firms will gain access to new followers and advisors that then provide valuable feedback on all aspects of their companies.

In addition the positive externalities, however, it is also possible that certain negative externalities may arise from equity crowdfunding. These negative externalities are likely to emanate from the requirements of the Federal JOBS ACT as interpreted by SEC rulings. Crowdfunding may:

(1) Cause companies to spend more time in educating investors. Companies who are selling securities pursuant to a crowdfunding offering may find themselves with a large base of "crowd" investors that may require them to expend more time and resources on their shareholder communications and investor relations than might otherwise be the case (e.g., additional solicitation efforts when seeking shareholder action and more regular reporting of financial and business results) (Fields 2013). 
(2) Add institutional costs to the disclosure process. Tier 2 investments will require both offering and post-offering disclosure requirements that might not be required by companies who are raising private equity capital by other means (including the ongoing annual financial disclosure that will be required) (Cheung 1987). However, at present it is not clear that this change will add much cost to the disclosure process used for other exempt offerings (Fields 2013). However, in addition, companies engaging in an equity crowdfunding offering, pursuant to the Crowdfunding Exemption, will be required by the federal legislation (not necessarily state legislation) to hire intermediaries (portals/platforms) to conduct the transactions, which may also map to added transaction costs (Dalhman 1979).

(3) Not be attractive to latter stage investors. As companies already engaged in a pre-seed or seed equity crowdfunding offering move along the equity financing continuum, they are likely to need or want to attract later round financing. Venture capital, private equity, or institutional financing sources may be reluctant to invest in an entity with a large base of "crowd" investors. They may prefer to deal with a traditionally smaller and more restricted class of accredited investors. Furthermore, if the company engages in a merger or acquisition, this action will need shareholder approval from their large base. Although these capital expansions would likely occur at later stages of company development, these transactions will require substantial shareholder communication that may be difficult to manage. This issue could potentially limit some companies from accessing capital at various stages of development unless the venture clearly demonstrates the efficiencies of share/unit holder information conduits via their own well-designed Internet platforms (Stocker 2012).

However, the above predictions of negative externalities may be substantially mitigated. Crowdfunding is an Internet- based phenomenon, and the Internet will likely solve many of the 
above cited issues. For example, start-ups and small businesses that are savvy about the impact of the Internet will likely create websites containing information blogs and other outreach tools to target their market customers. They may also use special log-in sections to communicate with their stockholders. These mechanisms can also be developed and maintained at a very low cost.

Overall, The new federal and state legislation on ECF has the potential to significantly increase the pool of potential investors available in the marketplace, as well as, the options available to small companies who are seeking financing. However, it is yet undetermined if it will act as a substitute for traditional means of financing or replace it in the near future. What is evident is that in the near future, the funding volume will continue to increase, new platforms will emerge while others cease to exist, and that a consolidation will ultimately occur in the market. Moreover, the federal and state legislation, regarding ECF will provide for more expansive total investments by developing a more efficient crowdfunding architecture and leveraging the geographic biases examined by Agrawal (2011). Some early-stage start-up companies may also use crowdfunding companies such as Kickstarter to fund pre-sales of their products (Wortham 2012), test their business ideas (Mollick 2014), get feedback about their product from the crowd awareness (Blohm et al. 2013; Giercak et al 2016), while others may use ECF as an alternative to their more conventional sources of funding (Stemler 2013; Yoichiro 2012). Especially for early stage companies that may not have sufficient availability of equity capital, the new U.S. legislation may allow them access to other useful sources. Rather than using an investment banker or other financial intermediary, they will be able to use ECF portals (Miller 2014) and potentially decrease time to fund and increase initial capital. Further, the investment banking community and the financial intermediary communities will likely make changes to meet the growth of crowdfunding as more new innovations in interest rates, 
instruments, and offerings are developed (Hemingway 2012). Crowdfunding is a dilated model of what disintermediated investment banking could look like (Rubinton 2011). Some organizations may choose to participate in this new venue by creating "clearing house" websites that enable investors to choose from a selection of offerings, or they may want to create restricted access portals for a particular level of investor. Existing entities that have offered access to pre-qualified accredited investors through restricted access internet portals will likely need to revise their vetting procedures if they wish to attract equity crowdfunders (Cifrino, Conaghan, Laurenson, Leder, Murphy, Orsic, Rochwarger, and Swartz 2013).

In spite of its limitations and obligations, ECF has the potential to provide many companies access to investors that they would not have been able to reach through traditional private placements prior to the passing of the JOBS Act or state ECF laws. Companies that are willing to comply with the JOBS Act or state requirements will be able to use ECF portals to find investors previously unavailable to them (McDermott 2012). Particularly for entrepreneurs, small businesses, and project-based initiatives, ECF has the potential to become a viable fundraising vehicle and a major alternative to traditional financing methods, such as banks loans, business angels, or venture capitalists, all of which are not always accessible to these entities.

\section{CONCLUSION \& DIRECTIONS FOR FUTURE RESEARCH}

This paper has compared traditional equity based financing regulations to the new federal JOBS Act and offered a comparison between federal and state laws as they pertain to crowdfunding. In addition, the paper has provided a conceptual framework depicting how crowdfunding may change the traditional equity-financing continuum, and also presented various externalities that may emanate from the implementation of crowdfunding. However, due to the limited scholarly research that is currently available on ECF within the U.S., it is our hope that 
this study will foster more discussion and once data is available, empirical research in the field. Moreover, we hope that more empirical research will be conducted to test our hypotheses, as well as the crowdfunding micro and macro externalities. We contend that the enumerated externalities in this study have the potential to generate multiple implications that can provide researchers with a diverse and critical set of future data-based research efforts.

While, ECF is still a relatively young market (Lambert and Schweinbacher 2010), particularly in the U.S, it is imperative that we gain a better understanding of the impact it will have on the economy by conducting more empirically based research. (Bruton et al 2015). It is also our hope that future information retrieved from ECF platforms and state security commissions within the U.S. will provide the data required to conduct the empirical testing of the conceptual model presented in this paper and to determine the overall effectiveness of equity crowdfunding in fostering economic development. 


\section{REFERENCES}

Agrawal, A. K., Catalini, C., and Goldfarb, A. 2013. "Some simple economics of crowdfunding.” (No. w19133). National Bureau of Economic Research, Cambridge, MA.

Agrawal, A. K., Catalini, C., and Goldfarb, A. 2011. "The geography of crowdfunding.” (No. w16820), National Bureau of Economic Research, Cambridge, MA.

Ahlers, G. K., Cumming, D., Günther, C., and Schweizer, D. 2012. "Signaling in equity crowdfunding”. Available at SSRN, 2161587.

Alois, J. D. 2013. "Equity crowdfunding platforms raising money now from accredited investors, Crowdfund Insider.” Retrieved from http://www.crowdfundinsider.com/2013/02/10285equity-crowdfunding-platforms-raising-money-now/

Alois, J. D. 2013. “Startup survey: 97\% want to invest in early stage companies.” Accessed on October 31, 2015 at http://www.crowdfundinsider.com/2015/10/76340-startup-survey97-want-to-invest-in-early-stage-companies/.

Alois, J. D. 2013. "SEC Meeting on Crowdfunding-Statement by Commissioner Piowowar." Crowdfund Insider. Retrieved from http://www.crowdfundinsider.com/2013/10/24975sec-meeting-crowdfunding-statement-commissioner-piwowar/.

Alsever, J. 2015. “Crowdfunding's secret benefit." Fortune. Retrieved from http://fortune.com/2015/03/08/crowdfunding-benefit/.

Bedino, C. and Castrataro, D. 2012. "Perché il crowdfunding non interessa alle banche?" Corriere della sera.it, Italy.

Belleflamme, P., Lambert, T., and Schwienbacher, A. 2013. "Individual crowdfunding practices." Venture Capital 15(4): 313-333. doi:10.1080/13691066.2013.785151 
Belleflamme, Paul, Thomas Lambert, and Armin Schwienbacher. "Crowdfunding: Tapping the right crowd." Journal of Business Venturing 29, no. 5 (2014): 585-609.

Blechman, B. 2012. “Democratization of Investing.” Wharton Magazine on-line 4.

Blohm, I., Sieber, E., Schulz, M., Haas, P., Leimeister, J. M., and Wenzlaff, K. 2014. “DelphiStudie Crowdfunding 2020.”-Komplement oder Substitut für die Finanzindustrie. Norderstedt: Books on Demand.

Bradford, C. S. 2012. "Crowdfunding and the federal securities laws." Columbia Business Law Review 1: 1-150.

Bruton, G., Khavul, S., Siegel, D., and Wright, M. 2015. "New financial alternatives in seeing entrepreneurship: microfinance, crowdfunding, and peer-to-peer innovations." Entrepreneurship Theory and Practice 39(1): 9-26.

Burtch, G., Ghose, A., and Wattal, S. 2013. "An empirical examination of the antecedents and consequences of contribution patterns in crowd-funded markets.” Information Systems Research 24(3): 499-519.

Burtch, G., Benedetto, C. A., and Mudambi, S. M. 2014. "Leveraging information systems for enhanced product innovation.” In F. J. Martınez-Lopez (Ed.), Handbook of strategic ebusiness management (211-216). Berlin: Springer.

Burton, D. 2012, August 30. "NSBA Comments to FINRA.” Retrieved from http://www.nsba.biz/wp-content/uploads/2013/01/NSBA-Comments-to-FINRA-reCrowdfunding-083012-Final.pdf

Bygrave, W. 2009, June 3. “The entrepreneurship paradigm revised: 20 years later.” Babson College Entrepreneurship Research Conference. Doctoral Consortium. Babson College, Massachusetts. 
Cardullo, M. 1999. Technological Entrepreneurism: Enterprise Formation, Financing, and Growth, (Abe Publishing, Research Series).

Cheung, N.S. 1987. "Economic organization and transaction cost." The New Palgrave: A Dictionary of Economics 2: 55-58.

Cholakova, M., and Clarysse, B. 2014. "Does the possibility to make equity investments in crowdfunding projects crowd out reward - based investments?" Entrepreneurship Theory and Practice 39(1): 145-172.

Cifrino, D. A., Conaghan, T. P., Laurenson, E. C., Leder, A., Murphy, T. J., Orsic, E., Rochwarger, J. P., and Swartz, Z. A. 2013. "United States: SEC approves changes to private offering rules and adopts new "bad actor" prohibitions; proposes additional changes to better monitor private offering market." Mondag. Retrieved from http://www.mondaq.com/unitedstates/x/253824/ Securities/SEC+Approves+Changes+To+Private+Offering+Rules+And+Adopts+New+B $\underline{\mathrm{ad}+\text { Actor+Prohibitions+Proposes+Additional+Changes+To+Better+Monitor+Private+Of }}$ fering+Market.

Crowdfunding conference and seminars 2013. Retrieved from http://www.crowdfundingconferenceseminar.com/media-libararycrowdfunding_planning-Conference-cloud_based_business_planningcrowdfunding_softwarecrowdfunding-crowdfunding_exchange/List-of-crowd-foundingsites.

Crowdexpert.com 2015. "How to guides." Retrieved from http://crowdexpert.com/how-toguides/regulation-a-corwdfunding/ 
Dahlman, C. 1979. “The problem of externality.” Journal of Law and Economics 22(1)" 141162.

Denis, D. J. 2004. “Entrepreneurial finance: An overview of the issues and evidence." Journal of Corporate Finance 10(2): 301-326.

Crowdsoucing.org 2015. "Directory of sites.” (n.d.). Retrieved from http://www.crowdsourcing.org/directory

Décarre, M. and Wetterhag, E. 2014. "Uncovering the outcomes of equity crowdfunding: Postfunding outcomes of equity crowdfunded firms in Europe.” Available at SSRN 545276.

Vismara, S. 2015. "Information cascades among investors in equity crowdfunding." Available at SSRN 2589619.

Emmerson, L. 2015. “Crowdfunding industry overtakes venture capital and angel investing. Crowdfunding trends.” Retrieved from http://blog.symbid.com/2015/trends/crowdfunding-industry-overtakes-venturecapital-and-angel-investing/

Fields, C. 2013. “Crowdfunding under the JOBS act.” Retrieved from http://www.carltonfields.com/crowdfunding-under-jobs-act/.

Financial Conduct Authority 2014. "The FCA's regulatory approach to crowdfunding over the internet, and the promotion of non-readily realizable securities by other mediaFeedback back to CP13/3 and final rules." Policy Statement (PS) 14/4. London: Financial Conduct Authority.

Fowler, B. 2015. “New Equity Crowdfunding Rules.” Legal IO. Retrieved from http://www.lawgives.net/blog/equity-crowdfunding-what-does-regulation-a-mean- 
Gage, D. 2012. “The venture capital secret: 3 out of 4 start-ups fail.” The Wall Street Journal. Retrieved from http://online.wsj.com/news/articles/SB10000872396390443720204578004980476429190

Gaskill, L. R., Van Auken, H. E., and Manning, R. A. 1993. "A factor analytic study of the perceived causes of small business failure.” Journal of Small Business Management 31 (4): $18-31$.

Gierczak, M. M., Bretschneider, U., Haas, P., Blohm, I., and Leimeister, J. M. 2016. "Crowdfunding: Outlining the New Era of Fundraising." In Crowdfunding in Europe (pp. 7-23). Springer International Publishing.

Gompers, P. A., and Lerner, J. 2004. The venture capital cycle. MIT press.

Gorman, M., and Sahlman, W. A. 1989. "What do venture capitalists do?” Journal of Business Venturing 4(4): 231-248.

Graham, P. 2005. "How to fund a start -up.” Y Combinator 11.

Grant, R. 2013. “SEC recognizes FundersClub as first-ever online VC.” Venture Beat. Retrieved from http://venturebeat.com/2013/03/28/sec-recognizes-fundersclub-as-first-ever-online$\underline{\mathrm{Vc} /}$

Harrrison, R. 2013. "Crowdfunding and the revitalization of the early stage risk capital market: catalyst or chimera?" Venture Capital 15(4):283-287.

Hemer, J. 2011. “A snapshot on crowdfunding.” (No. R2/2011). Working papers firms and region. Retrieved from https://search.yahoo.com/yhs/search;_ylt=A0LEVif37ipVekYARqcnnIIQ?ei=UTF$8 \& \mathrm{fr}=\mathrm{ytff} 1-\& \mathrm{hsimp}=\mathrm{yhs}-$ 
002\&hspart $=$ mozilla\&p $=\% 2 \mathrm{BHemer} \% 2 \mathrm{C}+\mathrm{J} .+\% 282011 \% 29 .+\mathrm{A}+$ snapshot + on + crowdfu nding \&fr2=sp-qrw-orig-top\&norw=1.

Hemingway 2012. "What is a security in the crowdfunding era?" Ohio State Entrepreneurial Business Law Journal 7(2): 335-371.

Hisrich, R., and Brusch, C. 1986. "Characteristics of the minority entrepreneur.” Journal of Small Business Management 24(4): 1-8.

Hornuf, L. and Schwienbacher 2014b. "Which securities regulations promotes crowdfunding?" Available at SRRN 2414124.

Hornuf, L. and Neuenkirch, M. 2015. "Pricing the value of cash flow rights in crowdinvesting: An analysis of innovestment backers.” Available at SRRN 2624908.

Kleemann, F., Voss, G., and Rieder, K. 2008. "Underpaid innovators: The commercial utilization of consumer work through crowdsourcing." Science, Technology \& Innovation Studies, 4 (1): 5-26.

Kortum, S., and Lerner, J. 2000. "Assessing the contribution of venture capital to innovation." RAND journal of Economics, 674-692.

Lambert, T., and Schwienbacher, A. 2010. “An empirical analysis of crowdfunding." Social Science Research Network. Retrieved from http://ssrn.com/abstract=1578175.

Lin, Mingfeng, and Siva Viswanathan. "Home bias in online investments: An empirical study of an online crowdfunding market." Management Science (2015).

Mass Solutions 2015. “Crowdfunding Industry Report.” Retrieved from http://www.crowdsourcing.org/editorial/global-crowdfunding-market-to-reach344b-in-2015-predicts-massolutions-2015cf-industry-report/45376 
McDermott, M. 2012. “Jobs act update: SEC misses rulemaking deadline.” Mercenary Trader. Retrieved from http://www.mercenarytrader.com/2012/07/ jobs-act-update-sec-missesrulemaking-deadline/.

Metrick, A., and Yasuda, A. 2011. Venture capital and the finance of innovation. Hoboken, NJ: John Wiley \& Sons.

Miller, B. 2013. "Crowdfunding will transform finance forever." The Fundrise Blog. Retrieved from http://blog.fundrise.com/post/51571350796/crowdfunding-will-transform-financeforever.

Miller, Z. 201). "Crowdbuilding: The real story behind crowdfunding that no one's telling. ” Forbes. Retrieved from http://www.forbes.com/sites/zackmiller/2014/01/13/crowdbuilding-the-real-story-behindcrowdfunding-that-no-ones-telling/.

Mixon III, S. S. A. M. 2008. Fool's gold?: The truth behind angel investing in America. Oxford: New York: Oxford University Press.

Mollick, E. 2014. “The dynamics of crowdfunding: An exploratory study.” Journal of Business Venturing 29(1): 1-16.

Moss, T. W., Neubaum, D. O., and Meyskens, M. 2014. "The effect of virtuous and entrepreneurial orientations on microfinance lending and repayment: A signaling theory perspective." Entrepreneurship Theory and Practice 39(1): 27-52.

Neiss, S. 2012, September 5. Crowdsourcing.org. Retrieved from http://www.crowdsourcing.org/editorial/crowdfunding-is-the-real-deal---a-report-fromthe-crowdfunding-bootcamp/20362 s. 
Ordanini, A., Miceli, L., Pizzetti, M., and Parasuraman, A. 2011. ”Crowd-funding: Transforming customers into investors through innovative service platforms." Journal of Service Management 22 (4): 443-470.

Ortmans, J. 2015. “Crowdfunding rules removed, what next.” Ewing Marion Kaufman Foundation, Policy Dialoge on Entrepreneurship 11.

Parker, S. C. 2014. “Crowdfunding, cascades and informed investors.” (No. 7994). IZA Discussion Paper.

SEC 2015. "Proposed rule amendments to facilitate intrastate and regional securities offerings." (2015, October 1). Retrieved from http://ftp.sec.gov/rules/proposed/2015/33-9973.pdf Regulation D Resources 2015. "Raise capital with regulation D.” Retrieved from http://regdresources.com/

Rubinton, B. 2011, April 11. “Crowdfunding: Disintermediated investment banking.” Retrieved from https://mpra.ub.uni-muenchen.de/31649/1/paper.pdf

SBA.gov 2015. "Small business trends impact.” Retrieved from https://www.sba.gov/content/small-business-trends-impact.

Schwartz, A. A. 2013. "Crowdfunding securities.” The Notredame Law Review 88 (3): 14571490.

Schwienbacher, A., and Larralde, B. 2010. "Crowdfunding of small entrepreneurial ventures." Retrieved from http://www. ema. eu/fileadmin/content/REALISE_IT_2/REALISE_IT_3. CROWD_OUP_Final_Version.pdf(June 5, 2014).

SEC 2015. "Jumpstart our business startups (JOBS) act.” Retrieved from https://www.sec.gov/spotlight/jobs-act.shtml.

SEC 2015. "SEC issues proposal on crowdfunding." Retrieved from http://www.sec.gov/rules. 
Senate Bill No. 3008, State of New Jersey, $215^{\text {th }}$ Legislature (2013). Retrieved from http://www.njleg.state.nj.us/2012/Bills/S3500/3008_I1.PDF.

Shane, S. 2008. "Angel groups: An examination of the Angel Capital Association survey." Case Western Reserve University, Cleveland, Ohio.

Sohl, J.E. 1999. "The early stage equity market in the USA." International Journal of Entrepreneurship and Finance 1(2): 101-120.

Registered Crowdfunding Portals 2015. Retrieved November 12, 2015, from https://www.ssb.texas.gov/texas-securities-act-board-rules/texas-intrastatecrowdfunding/registered-crowdfunding-portals

Stemler, A. R. 2013. "The Jobs Act and crowdfunding: Harnessing the power-and money—of the masses." Business Horizons 56(3): 271-275.

Statista.com 2015. "Statistics and facts about crowdfunding." Retrieved from http://www.statista.com/topics/1283/crowdfunding/.

Stuart, T.W., and Xu, X. 2003. "Liquidity events and the geographic distribution of entrepreneurship activity." Administrative Science Quarterly 48(2):175-201.

Stocker, M. 2012. "Startups, raising money by crowdfunding may scare off other investors." Retrieved from http://www.businessinsider.com/too-much-crowdfunding-can-scare-offinvestors-2012-8.

Tysiac, K. 2014. “Crowdfunding poses benefits, risks.” Journal of Accountancy. Retrieved from http://www.journalofaccountancy.com/News/20149550.htm.

Voorbraak, K. J. M. 2011. Crowdfunding for financing new ventures: Consequences of the financial model on operational decisions. Eindhoven Technical University, Belgium. 
Vismara, S. 2015. "Information cascades among investors in equity crowdfunding." Available at SSRN 2589619.

Wisconsin Act 52 2013. Retrieved from http://docs.legis.wisconsin.gov/2013/related/acts/52

World Bank 2013. "Crowdfunding's potential for the developing world.” Washington, DC: World Bank.

Wortham, J. 2012. "Success of crowdfunding puts pressure on entrepreneurs." The New York Times. Retrieved from hhtp://www.nytimes.com/2012/09/18/techonology/success-ofcrowdfunding-puts-pressure-on entreprenerus.html.

Yoichiro, T. 2012. “Crowdfunding: Its practical effect may be unclear until SEC rulemaking is complete." Retrieved from http://apps.americanbar.org/buslaw/blt/content/2012/05/article-03-taku.shtml

Zeoli, A. 2015. "State of the states - list of current active and proposed intrastate crowdfunding exemptions (updated).” Retrieved from http://crowdfundinglegalhub.com/2015/01/16/state-of-the-states-list-of-current-activeand-proposed-intrastate-exemptions/

Zvilichovsky, D., Inbar, Y., and Barzilay, O. 2014. "Playing both sides of the market: success and reciprocity on crowdfunding platforms." Available at SSRN 2304101. 